\title{
Job satisfaction of teachers working in the most difficult schools, with special reference to Puttalam Education Zone, Sri Lanka
}

\author{
Muddarage Lakshmi Hemamala Sumanasena ${ }^{1}$, Fareed Mohamed Nawastheen ${ }^{2 *}$ and Prabha Ransi \\ Jayawardena $\mathbf{3}^{\mathbf{3}}$ \\ ${ }^{\prime}$ WP/Co/Rajasinghe Maha Vidyalaya, Colombo 10, Sri Lanka. \\ ${ }^{2}$ Department of Secondary and Tertiary Education, Faculty of Education, The Open University of Sri Lanka, Nawala, Sri Lanka. \\ ${ }^{3}$ The Queensland University of Technology, Brisbane, Australia.
}

\begin{abstract}
The present study was aimed at identifying the job satisfaction of teachers working in the most difficult schools in the Puttalam Education Zone, Sri Lanka. The objectives were to examine whether there is any relationship between teachers' job satisfaction and intrinsic and extrinsic factors. A survey was carried out to identify teachers' attitudes towards their careers. Herzberg's Two Factor Theory was used as the theoretical framework for this study. Data was collected from 93 teachers working in the most difficult schools in the Puttalam Education Zone, through a self-developed, pre-tested questionnaire. The study sample was analysed through descriptive and inferential statistics. It was found that the majority of teachers were women and married. It is significant that more than $80 \%$ of teachers working in the most difficult schools have less than 10 years of teaching experience. There is a significant relationship between job satisfaction and intrinsic and extrinsic factors. Bi-variate analysis indicated that a sense of achievement of intrinsic factors and extrinsic factors, work conditions, pay and rewards have no significant relationship with teachers' job satisfaction. Moreover, there is a multi-collinearity between the independent variables. The study recommends that the state should address teachers' problems by providing them adequate teaching facilities, in-service training, promotions, accommodation and incentives, and revise transfer policies to motivate and retain teachers in the most difficult schools, to provide a long-term solution for teacher shortages in such schools in Sri Lanka.
\end{abstract}

Keywords: Teacher problems in remote schools, job satisfaction among teachers, education, Sri Lanka.

\section{INTRODUCTION}

Job satisfaction is an important topic in teacher education research. It focuses on teachers' occupational attitudes, zeal for teaching and work enthusiasm, all of which affect the quality of education (Fuming \& Jiliang, 2014). Job satisfaction is a combination of psychological, physiological and environmental circumstances (Sen, 2008). The concept of job satisfaction has received much attention in recent times. However, Elton Mayo's Hawthorne Study, conducted in the 1920s at the Western Electric Company, may be considered as the first research study on job satisfaction. It suggested that satisfied workers increase the productivity of an organisation (Jayathilake, 2014). Vroom defines job satisfaction as the affective orientations of individuals towards work roles which they are engaged in (as cited in Aziri, 2011). Locke's (1976) commonly used definition of job satisfaction highlights the positive emotional state of the mind that results from the job experiences, the positive attitudes or emotional dispositions that people may gain from work (as cited in Anderson et al., 2001). Employees' job satisfaction becomes a central concern in research in organisational psychology because it is believed to have a relationship with job performance.

Additionally, Mbua (2003) defines job satisfaction as the fulfilment acquired by experiencing various job activities and rewards. Robbins (2005) defines the concept job satisfaction as the employee's feelings about her or his job. According to Spector (1997: p. 2), job satisfaction is defined as "how people feel about different aspects of their jobs. It is the extent to which people like (satisfaction) or dislike (dissatisfaction) their jobs".

*Corresponding author (fmnaw@ou.ac.lk; (iD https://orcid.org/0000-0001-9538-7372)

This article is published under the Creative Commons CC-BY-ND License (http://creativecommons.org/licenses/ by-nd/4.0/). This license permits use, distribution and reproduction, commercial and non-commercial, provided that the original work is properly cited and is not changed anyway. 
According to Zymbylas \& Papanastaiou (2006), teachers' job satisfaction refers to the matters related to conditions like student achievement, decision-making ability, self-growth, and so on. They also state that societal relationships are important in job satisfaction; interactions with students, relationships with colleagues, and opportunities to contribute to the growth of individuals and the development of society are some factors that teachers always emphasise for their own satisfaction (Zymbylas \& Papanastaiou, 2006).

Amstrong (2006) defines job satisfaction as the attitudes and feelings people have about their work. Job satisfaction is always led by positive and favorable attitudes, while job dissatisfaction is indicated by negative and unfavorable attitudes towards the job. Most of these definitions suggest that job satisfaction refers to the feelings of the employee towards his or her work (Ali et al., 2015). George \& Jones (2005) define job satisfaction as the combination of feelings and beliefs, which include the mental, emotional and physical domains. Judge et al. (2012) note that job satisfaction is a set of psychological responses of an individual towards his or her job. These personal responses have three components: cognitive (evaluative), affective (or emotional) and behavioral.

On the basis of the above definitions, in this study, the researchers use the concept of teacher job satisfaction to mean teachers' attitudes, perceptions and feelings towards their job. It also describes whether teachers are happy with their job or not.

Attempts to improve performance in schools will never succeed if teachers are not effective or committed to work at school (Ogochi, 2014). Teachers' commitment and effectiveness solely depend on motivation and job satisfaction (Fuming \& Jiliang, 2014). This shows that teacher motivation and job satisfaction are important phenomena to uplift the quality of education. A survey conducted recently explains how lack of job satisfaction among teachers influences absenteeism, lateness and lack of commitment to their work (Shonje, 2016). Teachers' satisfaction is not only important to teachers themselves, but also to educational managers, leaders, employers, and most importantly, to students in all types of schools. According to Shann (2010), teacher satisfaction may be considered a predictor of teacher retention, a determinant factor of teacher commitment, and a contributor to school effectiveness. This shows that teacher job satisfaction is an important phenomenon for the entire education system. The research problem is generated against this backdrop.

Today, education is considered very important, not only as an individual right but also as a key factor in social and national development. Therefore, it has become one of the most vital areas of investment in any society since it boosts the productivity of a nation. A poor level of education may lead to economic, sociocultural, and environmental problems, directly affecting the development of a nation (Kappagode, 2013). Thus, it is important to develop the education system as a whole.

Teachers play a very significant role in the education system. It is believed that for a qualitative development in education, teacher job satisfaction is an essential phenomenon (Yusuf et al., 2015). An organisation gets effective work done by employees when they find satisfaction and meaning in work; but when satisfaction and meaning are lacking, individuals tend to withdraw in their work or rebel, and at the end, everyone loses (Klassen \& Chiu, 2010). However, it is disturbing to find that, nowadays, most teachers do not have job satisfaction. There seems to be a growing discontent on the part of the teachers towards their jobs, as the standards of education are falling (Premasiri, 2013). This brings out the importance of studying teachers' job satisfaction to bring about a qualitative development in education. In Sri Lanka, the government is devoted towards improving the quality of education at all levels; such efforts will become futile if teachers' motivation and job satisfaction are not addressed by school administrators (Premasiri, 2013). In Sri Lanka, there is a low performance of students in difficult areas mainly because of the shortage of teachers.

The reason for the shortage has been attributed to teachers' lack of satisfaction with the working conditions in rural areas. However, in the 1960s and 70 s, there was a qualitative improvement in the education in rural areas because of the Kannangara reforms which resulted in weakening the rural-to-urban migration of students as well as teachers. This situation drastically changed during the late 80s, with the introduction of the Provincial Council administration. Teachers in under-resourced schools try to get transfers to urban schools as they are not satisfied with the working conditions (Sri Lanka, Ministry of Education, 2004). It has been proposed in parliament to recruit 50,000 teacher assistants to overcome the shortage of teachers in difficult or rural areas as a shortterm strategy (Sri Lanka, Ministry of Education, 2013). However, long-term strategies are necessary to improve the working conditions of teachers to retain them in the most difficult schools. Thus, it is important to identify the factors which affect teachers' job satisfaction and ways to improve teachers' job satisfaction in the most difficult schools, as a long-term solution. According to Sri Lanka, Ministry of Education (2017), there were 74 most difficult schools in the Puttalam district.

The phenomenon of teacher job satisfaction has been widely studied for over six decades (Klassen \& Chiu, 
2010). However, there is limited literature about teachers' job satisfaction in developing nations, Sri Lanka in particular. Further, it is hard to find a study on teachers' job satisfaction, particularly in the most difficult schools. This situation led the researchers to study the job satisfaction of teachers working in the most difficult schools in the Puttalam Education Zone in Sri Lanka.

Around the world, poverty and remoteness present significant challenges to teachers in under-resourced schools (Sri Lanka, Ministry Education, 2013). Particularly in Sri Lanka, teachers serving in the most difficult areas experience various challenges, such as lack of access to transportation, cultural resources, or educational opportunities. Therefore, this paper endeavors to identify the determinants for teachers' job satisfaction, and to examine the association between intrinsic and extrinsic factors and the job satisfaction of teachers, to help policy makers or school administrators to find solutions for prevailing problems. Therefore, the main purpose of the study was to find the determinants and their relationship with the job satisfaction of teachers working in most difficult schools in the Puttalam Education Zone. To this end, the following objectives were developed:

- To examine the association between job satisfaction and intrinsic factors of teachers working in the most difficult schools in the Puttalam Education Zone

- To examine the association between job satisfaction and extrinsic factors of teachers working in the most difficult schools in the Puttalam Education Zone

\section{LITERATURE REVIEW}

The phenomenon of job satisfaction is closely related to motivation (Mbua, 2003). Motivation is a process which may lead to job satisfaction. It is believed that there is a positive correlation between motivation and job satisfaction, i.e. motivation increases with the increase in job satisfaction and vice-versa (Singh \& Tiwari, 2011). Although the two concepts of job satisfaction and motivation are not similar, they are associated with a personal feeling of achievement. The link between the two concepts suggests that theories of motivation are also regarded as theories of job satisfaction (Ngimbudzi, 2009). Theories of motivation are usually divided into two approaches: content theories and process theories. In other words, there are two categories of motivational theories, such as need theories and process theories (Lundberg et al., 2009). Content theories or need theories focus on satisfying the inner needs of a person or emotional aspects related with motivation (Lundberg et al., 2009). Major content theories include: Maslow's Hierarchy of Needs; Macgregor's Theory X and Theory Y; Herzberg's Two Factor Theory; McClelland's Achievement Motivation Theory; and Alderfer's Existence Theory. Process theories mainly focus on the actual process of motivation or peoples' cognitive aspects related to motivation. These explain how an employee's behavior is initiated. The major theories under this heading include Locke's Value Theory; Expectancy Theory; Equity Theory; Goal Theory; and Attribution Theory (Miner, 2005). Despite the different approaches suggested by the need and process theories of motivation, Herzberg's Two Factor Theory (also called Motivation/Hygiene Theory) has been suggested as more plausible for studying job satisfaction (Worlu \& Chidoze, 2012; Klassen \& Anderson, 2009; Anastasiou, 2014; Ngimbudzi, 2009 etc.). Moreover, since this study focuses on the job satisfaction of teachers who work in the most disadvantaged schools, the researchers employed need theory to address teachers' emotional aspects related to job satisfaction. Herzberg, after an extensive research on accountants' and engineers' job attitudes and satisfaction, produced a list of factors that contribute to satisfaction and dissatisfaction at work. He distinguished two sets of work factors that determined job satisfaction or dissatisfaction: motivational (intrinsic) factors and the hygiene (extrinsic) factors (Miner, 2005). Herzberg suggests that motivational factors lead to job satisfaction and hygiene factors lead to job dissatisfaction (Miner, 2005). According to Herzberg, satisfaction or dissatisfaction factors at work are not totally opposite in their nature but they bring out different attitudes in a worker towards the job he does (as cited in Fiore, 2004). However, some argue that these factors cannot be identified as motivation or hygiene factors always; they may differ according to the working context (Fiore, 2004). Workers who get high salaries in comparison with salary scales in other organisations may consider salary and rewards as a motivational factor rather than a hygiene factor. Herzberg's theory differs from those presented by Maslow and Alderfer, as the latter believed that needs always energise individuals.

In recent years, studies on job satisfaction suggest that it is a multi-dimensional phenomenon: therefore, scholars have identified various determinants for teachers' job satisfaction (Ngimbudzi, 2009). According to Herzberg, the phenomenon of job satisfaction is associated with five main factors: achievement, recognition, work itself, responsibility and advancement - these are referred to as motivators. Vroom suggests seven factors which affect job satisfaction: administration, promotion, job nature, superiors, salary remuneration, working conditions and colleagues (Aziri, 2011). Additionally, teachers derive their satisfaction from factors like fringe benefits, 
educational policies, administration, advancement opportunities, recognition and responsibilities (Talabi, 2016; Ngimbudzi, 2009).

Understanding the important factors affecting teacher job satisfaction is vital to support an educational system to succeed in its objectives. According to Bogler (2001), teachers' occupational perceptions strongly affect their satisfaction. Principals' transformational leadership affects teachers' satisfaction through their occupational perceptions. Hui et al. (2013) conducted a case study in China on school principals' leadership and decisionmaking styles and teacher job satisfaction. They found that there is a significant positive relationship between teachers' job satisfaction and principals' leadership and decision-making styles (Hui et al., 2013). They suggest that the relationship between the principal's leadership style and teacher job satisfaction is mediated by the principal's decision-making style.

Rahman (2008) examined job satisfaction among public and private college teachers in Bangladesh and focused on the influential factors contributing to the satisfaction and dissatisfaction of teachers. Rahman (2008) concluded that gender has a significant influence on job satisfaction, while age and job experience did not affect it much. Female respondents were found to be more satisfied than male counterparts. On the other hand, the type of colleges was found to be an influential factor in overall job satisfaction. The study shows that teachers are very sensitive about payment. The analysis also revealed that private college teachers enjoy more modern classroom equipment and technological facilities than public college teachers; therefore, the public school teachers become dissatisfied because of this disparity (Rahman, 2008).

Another study conducted by Mahmood et al. (2011) aimed to investigate the difference between gender (male and female teachers) and types of school (urban and rural) in relation to job satisfaction. According to their study, teachers are less satisfied with advancement, salary, supervision, human-relation and working conditions. While female teachers are more satisfied than the male teachers, there was no significant difference between urban and rural teachers' job satisfaction. This study suggests that support from the administration is an important factor for teacher's job satisfaction (Mahmood et al., 2011).

Pabla (2012) revealed that teachers working in schools in rural areas are less satisfied with their job than those teachers who work in the colleges located in the urban areas. The main reason for the above differences is the disparities between those schools. It was identified that intrinsic factors and extrinsic factors, such as salary, benefits, prestige, opportunities for professional advancement, level of personal and professional challenges, level of autonomy, decision-making authority, general working conditions, interactions with colleagues and interaction with students are influential factors for teachers' job satisfaction. It was clear that demographic factors do not affect teachers' satisfaction to a great extent (Pabla, 2012).

It is generally believed that the quality of classroom teachers has the greatest impact on the performance levels of students. Kappagode (2013), in his study of national schools of Sri Lanka, focused on a different dimension which affects teacher job satisfaction. He brings out the importance of the emotional intelligence of the principals and its relationship with teachers' job satisfaction. It was found that an emotionally intelligent principal is able to monitor his or her own behavior, as well as the behavior of the teachers, and build relationships with the latter. This was helpful to enhance the job satisfaction of the teachers. By understanding the teachers' attitudes, principals can motivate them and improve their job satisfaction, ultimately, improving the quality of teachers. Furthermore, the researcher suggests that all educators and policy makers need to be concerned with the emotional intelligence of the principals and its relationship with teachers' job satisfaction (Kappagode, 2013).

Dutta \& Sahney (2016) contribute to the current literature on teacher job satisfaction by exploring the mediating role of a school climate. They examined the relationships among principals' instructional and transformational leadership behaviors, teachers' perception of the school climate, their job satisfaction and student achievement. They found that a principal's leadership behaviors are not directly associated with either teacher job satisfaction or student achievement, and transformational leadership behaviors showed an indirect effect on teacher job satisfaction. It is also suggested that instructional leadership behaviors have positive relationships with teacher job satisfaction. Such principals are always considerate about providing adequate resources and facilities to the teachers, maintaining pupil-teacher ratios, keeping average class sizes, planning professional development for the teachers, etc; such efforts in turn boost teacher job satisfaction. The physical climate, however, appeared to play a dominating role in teacher job satisfaction. The study took into account only the instructional and transformational leadership behaviors of principals - this may be identified as a limitation of this study (Dutta \& Sahney, 2015). 
Singh et al. (2007) discuss the relationship between stress and job satisfaction, proposing that dual-career couples face unique problems in their work, family and personal arenas of life. The results indicate that prevention and reduction of stress is very important to enhance the job satisfaction of teachers of both genders (Singh et al., 2007). Wijerathne (2013) found from his study that teachers who were satisfied with their profession is more than those who were dissatisfied. He also suggests that school-based factors greatly influence job satisfaction (Wijerathne, 2013). It was identified that providing opportunities for professional development is also very important. Similarly, a study on the job satisfaction of secondary school teachers conducted by Panditharathne \& Wijesundara (2015) brings out that teachers are dissatisfied mostly with societal and school-level factors and with the opportunities for their professional development.

Very little research has emerged about the factors conducive to maintaining a quality teacher workforce in low-resource communities of developing countries. According to Sargent \& Hannum (2005), teacher retention is a growing concern, especially in low resource communities. They point out that the distribution of quality teachers is an essential factor and equally important for all schools. However, the recruitment and retention of qualified teachers tend to be problematic in areas of high-poverty and rural areas in developing nations. This leads to a situation in which the neediest children are often paired with the least-qualified teachers with other life challenges (Sargent \& Hannum, 2005).

Anastasiou (2014) has done a survey to identify the influential factors for job satisfaction and stress levels of secondary education teachers in northwest Greece. This study uses Herzberg's Two Factor Theory as the theoretical framework, with descriptive statistics, such as frequencies and percentages, to examine teachers' job satisfaction and stress levels. The study suggests that teachers generally are more satisfied with the intrinsic aspects of their work, such as student achievement, recognition from students and colleagues and selfgrowth. Despite these factors, teachers expressed dissatisfaction with the extrinsic aspects such as imposed educational changes over which they have little control, reduced autonomy, poor work conditions, heavy workloads, low professional status, low salaries and few opportunities for professional development. High levels of stress were exhibited among young female teachers. Environmental factors such as provision of ethical rewards, good working conditions, motivation by the school principal and participation in school administration and decision-making had positive effects on teachers' work performance (Anastasiou, 2014).
Reilly et al. (2014) conducted a study on teachers' self-efficacy beliefs, self-esteem and job stress as determinants of job satisfaction in Ireland. The results indicate no significant differences in job satisfaction, self-efficacy, self-esteem and perceived stress between male and female primary school teachers. There was no significant relationship between self-efficacy and job satisfaction. The years of teaching experience was found to have a weak negative relationship with job satisfaction. This suggests that as the number of years in teaching increases, job satisfaction decreases. While the perceived stress is the main predictor of job satisfaction, it was unclear what the main sources of stress are for teachers. This study brings out important details concerning the predictors of job satisfaction and their relationship with self-esteem and stress. These findings are in line with previous research on job satisfaction and work stress of teachers. The results of this study reflect the current situation of teachers' stress and job satisfaction. More effective and systematic training and professional development opportunities, teachers' participation in decision-making and better working conditions are the factors needed to improve job satisfaction and to reduce emotional work stress (Reilly et al., 2014).

Calimeris (2016) contributes to the current literature on teacher job satisfaction by exploring the relationship between job satisfaction and students' performance. The effects of teacher job satisfaction on student performance outcomes were measured using a multiple estimation method. The findings indicated that there is a positive relationship between the level of teacher job satisfaction and student performance; the researcher also suggests that the differences in teachers' opinions regarding intrinsic and extrinsic factors of job satisfaction affect the overall level of satisfaction within a school. The findings of this study suggest ways to school administrators and policy makers on how to improve students' performance; school administrators can practice flexible policies and procedures to support and give teachers autonomy in order to improve their satisfaction, helping to improve students' performance outcomes at little monetary cost (Calimeris, 2016).

Mertler (2002) has conducted a research on job satisfaction and perception of motivation among middle-school and high-school teachers. The results were then summarised for the total group, considering the demographic variables including gender, ethnicity, age and years of experience. Males reported a higher level of job satisfaction than females, while teachers who were new to the career and those nearing the end of their careers indicated higher levels of job satisfaction than teachers who were in the middle of their careers. A great proportion of teachers in their 20 s, as well as 
those in their early $50 \mathrm{~s}$, indicated a desire to stay in the teaching profession, while sub-urban settings reported significantly unmotivated teachers in comparison with urban or rural areas. In this study, males reported a higher level of job satisfaction than females: this finding is important since it is somewhat contradictory to the results of previous research (Mertler, 2002).

A study on whether principals' background and school processes are related to teacher job satisfaction brings out a different aspect of teacher satisfaction (Shen et al., 2012). The researchers built a series of models for their analysis, including the unconditional model, the control model, the principal's background model, and the school process model. The strength of this study is in using a nationally representative sample. The findings suggest that teachers are more satisfied with teaching as a career when they receive support from administrators and the cooperation from their colleagues, and principals' administrative leadership is important to develop a collaborative culture and supportive structure that facilitate teachers. Principals who work to reduce teacher frustrations increase teacher job satisfaction; on the other hand, the inconsistent behavior of principals contributes to teacher stress. This study addresses policymakers on how to improve teachers' career satisfaction and brings out the complexity of the phenomenon of teacher job satisfaction (Shen et al., 2012).

Klassen \& Anderson (2009) conducted a comparative study on job satisfaction of teachers in year 1962 and 2007. For this study, the researchers took 210 secondary teachers as the sample, comparing the results with a similar study in 1962 by Rudd \& Wiseman (Klassen \& Anderson, 2009). Herzberg's theory was used as the theoretical framework. The results suggest that the secondary teachers in the 2007 sample rated their job satisfaction significantly lower than the secondary teachers in Rudd \& Wiseman's 1960s sample (Klassen $\&$ Anderson, 2009). Today's teachers are less concerned about the factors of dissatisfaction and more concerned with the factors that were expected to contribute to job satisfaction. In 1962, teachers' top concerns were salary, human relations and the state of buildings and equipment, which are externally related. In sharp contrast, teachers in 2007 were concerned about the absence of satisfiers; that is, pupils' behavior and pupils' attitudes. This study points out that the shift over time in teachers' perceptions of the behavior of pupils needs to be addressed in a direct and systematic way by education officials, since the quality of teacher-student relationships not only influences teachers' job satisfaction but is also related to students' school academic outcomes (Klassen \& Anderson, 2009).

\section{METHODOLOGY}

This study was conducted with a survey research design using a quantitative approach. Using a stratified sampling technique, 93 of 890 teachers from the 74 most difficult schools in the Puttalam Education Zone (Sri Lanka, Puttalam Zonal Education Office, 2017) were selected as the sample for the study. Stratified sampling is an apposite technique for addressing specific subgroups within the population of a study. The population of this study consisted of male and female teachers, and unequal distribution of teachers across schools in the selected zone. Therefore, the researchers utilised a stratified sampling technique to select the sample for the study. To achieve the objectives of the study, a self-developed, pretested questionnaire was used to collect quantitative data. The questionnaire consisted of three parts: Part A with demographic factors; Part B to identify factors which affect job satisfaction. The third part of the questionnaire consisted of open-ended questions where the respondent could freely express his or her ideas. Respondents would mark the statements in the self-developed questionnaire using a 5-point Likert scale, ranging from Strongly Disagree (SD), Disagree (D), Neutral (N), Agree (A), and ending in Strongly Agree (SA). Numerical ratings for the responses were obtained by using values ranging from one point for Strongly Disagree to five points for Strongly Agree. The questionnaire was piloted three times with 20 teachers and necessary amendments were made prior to the main study, to maintain the validity of the questionnaire. Table 1 shows the internal consistency of the questionnaire.

Table 1 is the summary of the reliability test output. The Cronbach Alpha value of the questionnaire was 0.870 . It's accepted that the internal consistency of a questionnaire is good if its Cronbach's Alpha value is greater than or equal to 0.8 (Saunders et al., 2009). Therefore, the internal consistency of the questionnaire of the study was good. Post-testing of the internal consistency of the questionnaire is indicated in Table 2.

Table 2 is the summary of reliability test output. The Cronbach Alpha value of the questionnaire was 0.898 . That is nearly 0.9 . It's accepted that the internal consistency of the questionnaire is excellent if the Cronbach's Alpha value is greater than or equal to 0.9.

\section{DATA ANALYSIS AND FINDINGS}

In this study, six demographic characteristics were considered: gender, age and marital status, type of appointment, years of service and the highest educational 
Table 1: Reliability statistics of the pre-test questionnaire

\begin{tabular}{lrr}
\hline Cronbach's Alpha & Cronbach's Alpha based on standardised items & Number of items \\
\hline 0.870 & 0.889 & 52 \\
\hline
\end{tabular}

Table 2: Reliability statistics of post-test questionnaire

\begin{tabular}{lrr}
\hline Cronbach's Alpha & Cronbach's Alpha based on standardised items & Number of Items \\
\hline 0.898 & 0.897 & 52 \\
\hline
\end{tabular}

qualifications of teachers working in the most difficult schools. Table 3 shows the distribution of the sample based on the demographic variables.

According to the analysis of data, there were $66 \%$ female teachers and 34\% male teachers in the sample. Most of the teachers were married (66\%) while the unmarried percentage was $32 \%$. Only $2 \%$ of the respondents were widowed teachers. According to Table 3 , the majority of teachers were graduates and trained teachers with less than 10 years' service.

According to the Herzberg theory, job satisfaction is derived from motivational or intrinsic factors which are derived through the work individuals do. Five dimensions were identified as intrinsic factors that contribute to job satisfaction of teachers: sense of achievement, recognition, nature of work, responsibility, advancement and personal growth. Table 4 shows the mean and standard deviation of these variables, clearly indicating the contribution of intrinsic factors to teachers' job satisfaction.

According to Table 4, the results of the highest values of mean were found in the nature of work $(\mathrm{M}=14.9, \mathrm{SD}=2.4)$; advancement and personal growth $(\mathrm{M}=13.03, \mathrm{SD}=1.9)$; and recognition $(\mathrm{M}=12.14, \mathrm{SD}=1.9)$. The lowest scores of mean values were found in the sense of achievement $(\mathrm{M}=3.1, \mathrm{SD}=0.74)$ and responsibility $(\mathrm{M}=5.7, \mathrm{SD}=$ 1.11). These values show that the majority of teachers agree with the fact that intrinsic factors are influential for their job satisfaction. Further, Table 5 shows the mean and standard deviation values of extrinsic factors.

Seven variables were considered as extrinsic factors. They are: school policy and administration, supervision, interpersonal relationships, work conditions, pay and rewards, job security, and general attitudes towards

Table 3: Demographic characteristics of the respondents

\begin{tabular}{llrr}
\hline Category & Type & Frequency & $\%$ \\
\hline Gender & Male & 32 & 34.6 \\
& Female & 61 & 65.6 \\
Age & Below 30 years & 35 & 37.6 \\
& 30-40 years & 45 & 48.4 \\
& More than 45 years & 13 & 14 \\
Marital status & Married & 61 & 65.6 \\
& Unmarried & 30 & 32.3 \\
Appointment type & Widowed & 02 & 2.2 \\
& Untrained & 07 & 7.5 \\
& Trained & 41 & 44.1 \\
& Graduate & 37 & 39.8 \\
Experience & Trained Graduate & 08 & 8.6 \\
& Below 10 years & & 79.6 \\
& 10-25 years & 74 & 15.1 \\
& More than 25 years & 14 & 5.4 \\
\hline
\end{tabular}


job satisfaction among teachers who are working in the most difficult schools in the Puttalam Education Zone. According to Table 5, the results of the highest values of mean are found for the relevant institute's policy and administration $(\mathrm{M}=16.9, \mathrm{SD}=3.37)$, pay and rewards $(\mathrm{M}=14.07, \mathrm{SD}=4.25)$, general attitudes towards job satisfaction $(\mathrm{M}=13.6, \mathrm{SD}=2.5)$, supervision $(\mathrm{M}=12.12, \quad \mathrm{SD}=2.14)$, and working conditions $(\mathrm{M}=11.04, \mathrm{SD}=2.5)$. These values underline that the majority of teachers accepted that extrinsic factors influenced their job satisfaction.

Furthermore, Spearman's Rank Correlation was obtained to test the association between the job satisfaction of teachers in the most difficult schools (Y), intrinsic factors of teachers $\left(\mathrm{X}_{1}\right)$ and extrinsic factors of teachers $\left(\mathrm{X}_{2}\right)$. The Spearman correlation coefficients and $\mathrm{p}$-values of the hypothesis test for population correlations are given in Table 6 .

According to Table 6, the p-value for the correlation of $\mathrm{X}_{1}$ variable is 0.000 . It is less than the significance level. Therefore, motivational factors are significant at $1 \%$ and $5 \%$ levels. The correlation coefficient between job satisfaction and motivational factors is 0.500 . And there's a positive relationship between job satisfaction of teachers and intrinsic factors.

In addition, Table 6 demonstrates a linear relationship between job satisfaction of teachers and extrinsic factors, as its $\mathrm{p}$-value for correlation for the $\mathrm{X}_{2}$ variable is 0.022 at $5 \%$ significance level. This means that extrinsic factors are also influential factors for job satisfaction among teachers who work in the most difficult schools. However, the relationship is not significant at $1 \%$. Accordingly, the strength of the relationship between job satisfaction and extrinsic factors is weaker than the relationship between job satisfaction and intrinsic factors. A significant relationship between the independent variables of the study is known as a multi co-linearity. Table 6 shows the multi co-linearity in the independent variables. The $\mathrm{p}$-value for the correlation between $X_{1}$ and $X_{2}$ is 0.001 . It is less than the significant level of 0.01 . Therefore, there is a significant relationship between the intrinsic and extrinsic factors of teachers. The coefficient correlation of these two variables is 0.345 .

Further, Table 7 shows the relationship between job satisfaction of teachers $(\mathrm{Y})$ and bi-variables (dimensions) of the main variables. The intrinsic factors $\left(X_{1}\right)$ were measured in five dimensions: sense of achievement $\left(\mathrm{X}_{11}\right)$, recognition $\left(\mathrm{X}_{12}\right)$, nature of work $\left(\mathrm{X}_{13}\right)$, responsibility $\left(\mathrm{X}_{14}\right)$ and advancement and personal growth $\left(\mathrm{X}_{15}\right)$. The extrinsic factors $\left(\mathrm{X}_{2}\right)$ were measured in six dimensions: company policy and administration $\left(\mathrm{X}_{21}\right)$, supervision $\left(\mathrm{X}_{22}\right)$, working conditions $\left(\mathrm{X}_{23}\right)$, interpersonal relationships $\left(\mathrm{X}_{24}\right)$, pay and rewards $\left(\mathrm{X}_{25}\right)$ and job security $\left(\mathrm{X}_{26}\right)$. In this analysis, the variable general attitudes towards job satisfaction was excluded as it was not directly influencing extrinsic factors.

Table 4: Mean and Standard deviation of intrinsic factors

\begin{tabular}{lrr}
\hline Intrinsic factors & Mean & Standard deviation \\
\hline Sense of achievement & 3.1720 & 0.74635 \\
Recognition & 12.1478 & 1.90117 \\
Nature of work & 14.9720 & 2.44551 \\
Responsibility & 5.7903 & 1.11882 \\
Advancement and personal growth & 13.0376 & 1.98874 \\
\hline
\end{tabular}

Table 5: Mean and Standard deviation of extrinsic factors

\begin{tabular}{lrr}
\hline Extrinsic factors & Mean & Standard deviation \\
\hline Policy and administration & 16.9444 & 3.37441 \\
Supervision & 12.1210 & 2.14603 \\
Interpersonal relationships & 6.3441 & 1.01075 \\
Working conditions & 11.0457 & 2.53828 \\
Pay and rewards & 14.0735 & 4.25007 \\
Job security & 11.9220 & 2.02531 \\
Gen. attitudes on job satisfaction & 13.6667 & 2.50525 \\
\hline
\end{tabular}


Table 7 summarises the relationship between job satisfaction and the bi-variables. It is very remarkable that a sense of achievement has no association with job satisfaction as its p-value is greater than the significance level.

All the other bi-variables of the intrinsic factorsnature of work, recognition, responsibility, advancement and personal growth-have a relationship with job satisfaction. Recognition is significant at $1 \%$ significance level. There's a positive linear relationship with job satisfaction. Recognition means the reputation that a teacher gains from the school community. The meaningfulness of the work and its suitability for the individual's professional and academic qualifications may be considered as the nature of work. According to Table 7, the relationship between the nature of work and job satisfaction is also significant. In any organisation, delegating responsibilities is very important for output. In a school context, teachers are responsible not only for the subject they teach; she or he is given other responsibilities too. Table 7 indicates that responsibilities are also another influential factor for a teacher's job satisfaction. Advancement is an indicator of upward mobility. It refers to career advancement as well as personal growth. According to Table 7, the factor advancement and personal growth is also significant at 0.01 significance level; it has a positive relationship with job satisfaction which has a

Table 6: Spearman Correlation Matrix for the dependent and independent variables

\begin{tabular}{lrrr}
\hline Variables & $\mathrm{Y}$ & $\mathrm{X}_{1}$ & $\mathrm{X}_{2}$ \\
\hline $\begin{array}{l}\text { Job satisfaction of teachers } \\
\text { in most difficult schools }(\mathrm{Y})\end{array}$ & 1.000 & $0.500^{* *}$ & $0.237^{*}$ \\
& & $(\mathrm{p}=0.000)$ & 1.000 \\
Intrinsic factors of teachers & $0.500^{* *}$ & & $0.022)$ \\
$\left(\mathrm{X}_{1}\right)$ & $(\mathrm{p}=0.000)$ & $0.345^{* *}$ \\
Extrinsic factors of teachers & $0.237^{*}$ & $(\mathrm{p}=0.001)$ & $(\mathrm{p}=0.001)$ \\
$\left(\mathrm{X}_{2}\right)$ & $(\mathrm{p}=0.022)$ & & 1.000
\end{tabular}

${ }^{* *}$ Correlation is significant at the 0.01 level (2-tailed).

* Correlation is significant at the 0.05 level (2-tailed).

Table 7: Correlation between job satisfaction and the bi-variables of independent variables of job satisfaction

\begin{tabular}{llrr}
\hline Variable & Bi-variables & Spearman Correlation & Sig. ( 2-tailed) \\
\hline Job satisfaction & & 1.000 & \\
Intrinsic (motivational) factors $\left(\mathrm{X}_{1}\right)$ & Sense of achievement $\left(\mathrm{X}_{11}\right)$ & 0.156 & 0.136 \\
& Recognition $\left(\mathrm{X}_{12}\right)$ & $0.376^{* *}$ & 0.000 \\
& Nature of work $\left(\mathrm{X}_{13}\right)$ & $0.477^{* *}$ & 0.000 \\
& Responsibility $\left(\mathrm{X}_{14}\right)$ & $0.426^{* *}$ & 0.000 \\
& Advancement and personal growth $\left(\mathrm{X}_{15}\right)$ & $0.424^{* *}$ & 0.000 \\
& & & $0.341^{* *}$ \\
Extrinsic (hygiene) factors $\left(\mathrm{X}_{2}\right)$ & $0.270^{* *}$ & 0.001 \\
& Company policy and administration $\left(\mathrm{X}_{21}\right)$ & 0.134 & 0.009 \\
& Supervision $\left(\mathrm{X}_{22}\right)$ & $0.341^{* *}$ & 0.200 \\
& Work conditions $\left(\mathrm{X}_{23}\right)$ & 0.057 & 0.001 \\
& Interpersonal relationships $\left(\mathrm{X}_{24}\right)$ & $0.455^{* *}$ & 0.584 \\
& Pay and rewards $\left(\mathrm{X}_{25}\right)$ & & 0.000 \\
\hline
\end{tabular}

${ }^{* *}$ Correlation is significant at the 0.01 level (2-tailed).

${ }^{*}$ Correlation is significant at the 0.05 level (2-tailed). 
0.424 magnitude in correlation. In this study, some of the bi-variables of extrinsic factors showed an association with job satisfaction. The relationship between job satisfaction with school policy and administration, supervision, interpersonal relationships and job security is significant. They showed a weak linear relationship. With regard to school administration, a principal's leadership qualities and school practices are very important aspects. Supervision is also significant at 0.01 significance level, showing a positive linear relationship with job satisfaction. Supervision refers to internal and external supervision. Interpersonal relationships are also influential for teachers' job satisfaction. The magnitude of its correlation is 0.341 at $1 \%$ significance level. These bi-variables have a weak correlation with job satisfaction comparing to the intrinsic factors. P-values for work conditions and, pay and rewards are greater than the significance levels. Hence, there is no significant relationship between job satisfaction and work conditions, and pay and rewards. Although, most studies held in a managerial context suggest that pay and rewards are determinant factors for job satisfaction, in this study they are not significant.

In addition, teachers responded to the following open-ended questions:

- Are teachers happy about their career?

- How do they feel working in a most difficult school?

- What are the obstacles and challenges faced by the teachers in the most difficult schools?

It was apparent that most of the teachers are happy working in the most difficult schools. They are satisfied with their job for many reasons. Some of their attitudes were expressed as follows:

"It is challenging to work in a most difficult school. However, it's more meritorious to support these innocent students who get very few chances in society. So, I work very happily in this school. My difficulties are forgotten when I see the happy faces of these innocent children".

"This is a good experience for me. Many teachers do not get the chance of having such experience. In that way we are lucky".

"In these schools we mostly care to retain students at least for the mandatory schooling period instead of focusing on their achievements. Sometimes we visit their homes to encourage them to continue schooling. So, we feel that our efforts are worth than money".
However, a common complaint of the teachers of these schools was that the transfer system should be revised with more consideration paid to teachers working in the most difficult schools. The researchers found a different idea among one of the teachers:

"I have been working here for nearly six years. Still I feel very sorry about these students and I like to be here and teach them as they need our support and guidance the most. If I get a transfer, it may take months or years to fill that vacancy".

The specific reasons why teachers are happy can be summarised as follows:

- Because they are teaching children of underprivileged families

- Because of the experience teachers gain in a most difficult school

- Because of the appreciation teachers gain from the school community

Likewise, teachers who work in most difficult schools face some unique challenges in comparison with their urban counterparts. Factors such as students' negative attitude towards learning; minimal parental involvement in children's learning; a lack of understanding among parents and students concerning the importance of education; workload pressures as a result of shortage of teachers in these areas; limited access to resources; and difficulties in travelling, negatively affect teachers' satisfaction, leading to frustration and stress. Furthermore, although teaching in a remote context provides leadership opportunities, most teachers are dissatisfied with having to take on extra responsibilities even though they are less experienced teachers.

\section{CONCLUSIONS AND RECOMMENDATIONS}

This study examined the factors that are associated with teachers' job satisfaction. After analysing the data, the following conclusions were drawn in relation to the research objectives. As far as the research objectives are concerned, there's an association between job satisfaction and intrinsic and extrinsic factors. A descriptive analysis of data brings out important factors about the nature of the sample and about its nature of distribution. A clear picture about the sample with respect to their age, service, marital status, experience and qualifications emerged and it was helpful for the researchers to draw conclusions from the study.

It was found that more than three-fourths of the teachers are below 40 years of age with less than ten 
years of teaching experience. This is an eye-opener for education authorities as it suggests that a comparatively small number of experienced teachers are found in the most under-served schools of Sri Lanka. When it comes to their type of appointment and highest educational qualifications, the results suggest that there are very few graduate teachers with postgraduate diplomas in the most under-resourced schools. This brings out the point that these teachers have few opportunities, or they are not encouraged to join professional development programs. This may influence teachers' job satisfaction and student performance as well. When considering teachers' gender and marital status, two-thirds of teachers were female and married.

The researchers conclude that many teachers may have personal problems relating to family matters in addition to their work at school. Descriptive statistics reveal that the majority of teachers in the most schools agree that intrinsic factors are influential upon their job satisfaction and the contribution of these factors towards job satisfaction is remarkable. Nearly half of the teachers agree with the point that there is a relationship between extrinsic factors and teachers' job satisfaction, while others disagree. This is a very alarming finding of this study and points to the need for an in-depth study on the bi-variables of the extrinsic factors.

It was also found that intrinsic factors and extrinsic factors have positive linear relationships with job satisfaction of the teachers working in most difficult schools. Out of the five bi-variables of motivational factors, only a sense of achievement has no relationship with teachers' job satisfaction. This confirms that there is no influence of students' performance on teachers' satisfaction. All the other bi-variables of intrinsic factors, nature of work, recognition, responsibilities, and teachers' advancement and personal growth, have a positive linear relationship with teachers' job satisfaction.

Further, a positive linear relationship with teachers' job satisfaction and extrinsic factors is revealed. However, extrinsic factors have a weaker relationship with job satisfaction in comparison with intrinsic factors. School policy and administration, supervision, interpersonal relationships, and job security contribute significantly to teachers' job satisfaction in most difficult schools. These results suggest that policy makers and administrators need to pay special attention to these dimensions to retain teachers in such schools.

Teachers' responses to the open-ended questions brought out very important suggestions to improve the job satisfaction of teachers working in the most difficult schools. According to their responses, teachers try to get transfers to urban schools or sometimes they quit their job as they become dissatisfied with the above mentioned factors. Spector (1997) suggests that employees tend to stay in jobs when they are satisfied with their jobs. Most teachers working in difficult schools are unhappy with the prevailing transfer system, suggesting the need for reforms. Moreover, the point was made that teachers who are very dedicated to working in these schools and those who have many years' experience should be identified, and their untiring work recognised. These suggestions will be helpful for the authorities to uplift the qualitative standard of education in Sri Lanka.

The majority of students in most difficult schools need individual attention as they come from less-privileged families and less-privileged social backgrounds. Therefore, teachers believe that the number of students in a class should be small. However, the actual situation is totally opposite as there is an inadequate number of teachers in most of these schools. There is a serious issue regarding the number of teachers as demonstrated by the teacher-student ratio. The authorities need to take action to retain teachers in these schools.

Revision of circulars to increase incentives is a remedial measure which can be put into practice by the authorities. It was found that teachers become frustrated as the students' attendance rates are very low. To overcome this problem, it was suggested that the school environment and classrooms should be more attractive for students. There should be a supportive and friendly environment for students. Teachers should be equipped with the necessary resources and instruments to teach in a friendly and attractive manner as a solution for students' absenteeism.

It is highly recommended that there should be a close relationship between teachers and parents. As most of the parents of these students are not educated, they do not understand the importance of schooling. Such parents promote their home industry rather than education. Thus, parents' attitudes towards education have to be made positive as an initial step. This may lead to better teacher satisfaction as they feel that they are doing meaningful work for society.

Improving the teachers' relationship with the school community is very important. In addition, supervision and evaluating processes should be modified. The prevailing process of supervision is another weak point encountered in this study. Monitoring takes place under three broad avenues, namely, team inspection, individual supervision and internal supervision. However, these monitoring processes are not effective much and teachers do not get effective solutions for the practical problems 
they face. Many teachers believe that the support given to them by the In-Service Advisors (ISA) was minimal. Therefore, it is recommended that supervision should be with ISA's greater involvement. School-based teacher development programs can be implemented to overcome their problems.

The results of this study support Herzberg's Two Factor Theory to a great extent. This study found that the fulfillment of most of the intrinsic factors result in job satisfaction among teachers. However, sense of achievement does not result in satisfaction in work as its relationship with job satisfaction was not significant. Further research might be conducted over a greater period of time and a variety of contexts, as this study was only a small-scale one in a specific context, carried out over a period of only six months. Furthermore, the present study focused only on the Puttalam district. Thus, the focus was limited to one particular area. Future studies should cover all the districts in Sri Lanka.

\section{REFERENCES}

Ali, A. A., Edwin, O. \& Tirimba, O. I. (2015) Analysis of extrinsic rewards and employee satisfaction: case of Somtel Company in Somaliland, International Journal of Business Management and Economic Research, 6(6), pp: 417-435 [Online] Available from: www.ijbmer.com/docs/volumes/ vol6issue6/ijbmer2015060609.pdf [Accessed: $17^{\text {th }}$ June 2017].

Anastasiou, S. (2014) Factors affecting job satisfaction, stress and work performance of secondary education teachers in Epirus, NW Greece, International Journal of Educational Management, 8(01), pp: 37-53 [Online] Available from: http:// www.researchgate.net/publication/264812614 [Accessed: $14^{\text {th }}$ June 2017].

DOI: https://doi.org/10.1504/ijmie.2014.058750

Anderson, N., Ones, D., Sinanajil, H. \& Visweswaran, C. (2001) Handbook for Industrial, Work and Organizational Psychology- Volume 02: Organizational Psychology, New Delhi: Sage Publications.

Armstrong, M. (2006) A Handbook of Human resource Management Practice, $10^{\text {th }}$ Ed., London: Kogan Page Publishing.

Aziri, B. (2011) Job satisfaction: a literature review, Management Research and Practice, 3(4), pp: 77-86 [Online] Available from: mrp.ase.ro/no34/f7.pdf [Accessed: $15^{\text {th }}$ June 2016].

Bogler, R. (2001) The influence of leadership style on teacher job satisfaction, Educational Administration Quarterly, 37(5), pp: 662-683.

DOI: https://doi.org/10.1177/00131610121969460
Calimeris, L. (2016) Does happiness matter? The effect of teacher job satisfaction on productivity, SSRN (July 22, 2016). DOI: https://doi.org/10.2139/ssrn.2821313

Dutta, V. \& Sahney. S. (2016) School leadership and its impact on student achievement: the mediating role of school climate and teacher job satisfaction, International Journal of Educational Management, 30(6), pp: 941-958.

DOI: https://doi.org/10.1108/ijem-12-2014-0170

Fiore, J. D. (2004) Introduction to educational administration: standards, theories and policies, New York: Eye on Education.

Fuming, X. \& Jiliang, S. (2014) Research on job satisfaction of elementary and high school teachers and strategies to increase job satisfaction, Chinese Education \& Society, 40(5), pp: 8696.

DOI: https://doi.org/10.2753/ced1061-1932400509

George, J. M. \& Jones, G. R. (2005) Understanding and managing organizational behavior, Upper Saddle River, New Jersey: Pearson Prentice Hall.

Hui, H., Hashem, S., Ismail, N. \& Radzi, C. W. (2013) Principal's leadership style and teacher job satisfaction: a case study in China, Interdisciplinary Journal of Contemporary Research in Business, 5(4), pp: 175-184 [Online] Available from:https://papers.ssrn.com/sol3/papers.cfm?abstract_ $\mathrm{id}=2378172$ [Accessed: $12^{\text {th }}$ June 2017].

Jayathilake, M. (2014) A study on job satisfaction among extension officers in the department of animal production and health in Rathnapura district, M. PM., Sri Lanka Institute of Development Administration.

Judge, T. A., Hulin, C. H. \& Dalal, R. S. (2012) Job satisfaction and job affect, In Kozlowski, S. W. J. (ed.) The Oxford Handbook of Industrial and Organizational Psychology-Volume 01, New York: Oxford University Press.

DOI: https://doi.org/10.1093/oxford-

$\mathrm{hb} / 9780199928309.013 .0015$

Kappagoda, U. W. M. R. S. (2013) The impact of five-factor model of personality on organizational commitment of English teachers in Sri Lankan government schools, International Journal of Physical and Social Sciences, 3(1) [Online] Available from: https://ssrn. com/abstract $=2220719$ [Accessed: 10 ${ }^{\text {th }}$ August 2017].

Klassen, R. M. \& Anderson, C. (2009) How times change: secondary teachers' job satisfaction and dissatisfaction in 1962 and 2007, British Educational Research Journals, 35(5), pp: 745-759.

DOI: https://doi.org/10.1080/01411920802688721

Klassen, R. M. \& Chiu, M. M. (2010) Effects on teachers' self-efficacy and job satisfaction: teacher gender, years of experience, and job stress, Journal of Educational Psychology, 
102(3), pp: 741-756.

DOI: https://doi.org/10.1037/a0019237

Locke, E. A. (1976) The nature and causes of job satisfaction, In Starbuck, W. H \& Dunnette, M. D. (eds.) Handbook of industrial and organizational psychology, pp: 1297-1343, Chicago: Rand McNally

Lundberg, C., Gudmundson, A. \& Andersson, T. D. (2009) Herzberg's two-factor theory of work motivation tested empirically on seasonal workers in hospitality and tourism, Tourism Management, 30(6), pp: 890-899.

DOI: https://doi.org/10.1016/j.tourman.2008.12.003

Mahmood, A., Nudrat, S., Asdaque, M., Nawaz, A. \& Haider, N. (2011) Job satisfaction of secondary school teachers: a comparative analysis of gender, urban and rural schools, Asian Social Science, 7(8), pp: 203-206.

DOI: https://doi.org/10.5539/ass.v7n8p203

Mbua, F. (2003) Educational administration: theory and practice, Limbe, Cameroon: Design House.

Mertler, C. A. (2002) Job satisfaction and perception of motivation among middle and high school teachers, American Secondary Education, 3(1), pp: 43-53 [Online] Available from: http://www.jstor.org/stable/41064589 [Accessed: 08 ${ }^{\text {th }}$ January 2018].

Miner, J. B. (2005) Organizational behavior 1: Essential theories of motivation and leadership, Armonk, NY: M. E. Sharpe.

Ngimbudzi, F. W. (2009) Job satisfaction among secondary school teachers in Tanzania: the case of Njombe District, M. Ed., University of Jyvaskyla [Online] Available from: https://jyx.jyu.fi/dspace/bitstream/handle/123456789/25482/ urn:nbn:fi:jyu201010152985.pdf? sequence $=1$ [Accessed: $20^{\text {th }}$ July 2017].

Ogochi, G., Kilgoris, R. \& Campus, K. (2014) Job satisfaction and teacher effectiveness in selected secondary schools in Trans Mara West District, Kenya, Journal of Education and Practice, 5(37), pp: 125-140.

Pabla, D. M. (2012) A study of job satisfaction among teachers of professional colleges in Punjab, Indian Journal of Research, 1(10), pp: 112-113.

Panditharatne, P. \& Wijesundara, S. (2012) A Study on the Job Satisfaction of Secondary School Teachers: The Case of Kandy District in Sri Lanka, Proceedings of the Abstracts of Jaffna University International Research Conference, 20th July 2012, Jaffna, Sri Lanka: University of Jaffna.

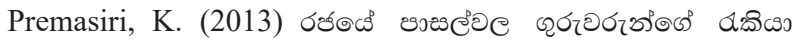

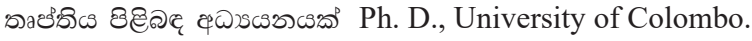

Rahman, M. I. (2008) Job satisfaction among public and private college teachers of Dhaka City: a comparative analysis, SSRN. DOI: https://doi.org/10.2139/ssrn.1737285
Reilly, R., Dhingra, K. \& Boduszek, D. (2014) Teachers' selfefficacy beliefs, self-esteem and job stress as determinants of job satisfaction, International Journal of Educational Management, 28(4), pp: 365-378.

DOI: https://doi.org/10.1108/ijem-04-2013-0053

Robbins, S. (2005) Organizational behavior, Pearson Education Asia.

Sargent, T. \& Hannum, E. (2005) Keeping teachers happy: Job satisfaction among primary school teachers in rural northwest China, The University of Chicago Press Journals, 49(02), pp: 173-204.

DOI: https://doi.org/10.1086/428100

Saunders, M., Lewis, P. \& Thornhill, A. (2009) Research methods for business students, London, UK: Pearson Education Limited.

Sen, K. (2008) Relationship between job satisfaction \& job stress amongst teachers \& managers, Indian Journal of Industrial Relations, 44(01), pp: 14-23 [Online] Available from: https://www.questia.com/library/.../relationship-between-jobsatisfaction-job-stress [Accessed: $16^{\text {th }}$ June 2017].

Senge, J. (2000) Who is a teacher? Quality teachers for quality education http://hakielimu.org/files/publications/WHO IS A TEACHER_R.pdf

Shann, M. H. (2010) Professional commitment and satisfaction among teachers in urban middle schools, The Journal of Educational Research, 92(2), pp: 67-73.

DOI; https://doi.org/10.1080/00220679809597578

Shen, J., Leslie, J. F., Spybrook, J. K. \& Ma, X. (2012) Are principal background and school processes related to teacher job satisfaction?, American Educational Research Journal,49(2), pp: 200-230.

DOI: https://doi.org/10.3102/0002831211419949

Shonje, G. N. (2016) The influence of working conditions on teachers job satisfaction: the case of Kisarawe District public secondary schools teachers in Tanzania, Ph. D., The Open University of Tanzania [Online] Available from: http:// repository.out.ac.tz/1575/1/GERALD_NTAGAHALI_ SHONJE.pdf [Accessed: 02 ${ }^{\text {nd }}$ September 2017].

Singh, S. K. \& Tiwari, V. (2011) Relationship between motivation and job satisfaction of the white-collar employees: a case study, Management Insight, 7(02).

Singh, T., Singh, A. \& Singh, P. (2007) Relationship of stress and job satisfaction: a comparative study of male $\&$ female of dual career teacher couples of India, IIM Bangalore Research paper No. 263, pp: 1-29.

DOI: https://doi.org/10.2139/ssrn.2144720

Spector, P. (1997) Job satisfaction: application, assessment, causes and consequences, Thousand Oaks, CA: Sage Publications. 
Sri Lanka, Ministry of Education (2004) The Development of Education- National Report, In UNESCO International Bureau of Education, $47^{\text {th }}$ session of the International Conference on Education, Geneva, Switzerland, 8-11 September 2004 [Online] Available from: http://www.ibe.unesco.org/sites/ default/files/Finrep_eng.pdf [Accessed: $03^{\text {th }}$ June 2018].

Sri Lanka, Ministry of Education (2013) Education firstSri Lanka [Online] Available from: https://planipolis.iiep. unesco.org/sites/planipolis/files/ressources/sri_lanka_ education_first_2013.pdf [Accessed: $11^{\text {th }}$ May 2017].

Sri Lanka, Ministry of Education (2017) Classification of schools by difficulty level- 2017 [Online] Available from: https://dmb.moe.gov.lk/EduStat/Publication/2017/03/03_PDF/ Tb120170309.pdf [Accessed: $11^{\text {th }}$ May 2017].

Sri Lanka, Puttalam Zonal Education Office (2017) List of difficult schools in Puttalam Zone, Unpublished statistical report, Puttalam: Puttalam Zonal Education Office.

Talabi, A. S. (2016) Job satisfaction and work performance of public secondary school teachers in Akoko North West local government area of Ondo state, Journal of Arts and Humanities, 5(08), pp: 39-49 [Online] Available from: www. theartsjournal.org/index.php/site/article/view/959 [Accessed: 09 ${ }^{\text {th }}$ March 2019].

DOI: https://doi.org/10.18533/journal.v5i8.959

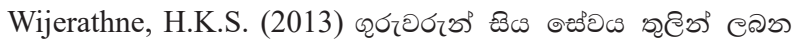

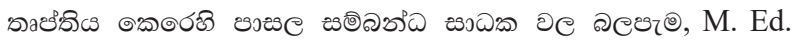
Thesis, The Open University of Sri Lanka.

Worlu, R. \& Chidozie, F. (2012) The validity of Herzberg's dual-factor theory on job satisfaction of political marketers, African Research Review, 6(1), pp: 39-50.

DOI: https://doi.org/10.4314/afrrev.v6i1.4

Yusuf, F. A., Olufunke, Y. R. \& Valentine, M. D. (2015) Causes and impact of stress on teachers' productivity as expressed by primary school teachers in Nigeria, Creative Education, 6, pp: 1937-1942.

DOI: https://doi.org/10.4236/ce.2015.618199

Zembylas, M. \& Papanastasiou, E. (2006) Sources of teacher job satisfaction and dissatisfaction in Cyprus, Compare: $A$ Journal of Comparative and International Education, 36(2), pp: 229-247.

DOI: https://doi.org/10.1080/03057920600741289 